NBER WORKING PAPER SERIES

\title{
WORKFARE AND HUMAN CAPITAL INVESTMENT: EVIDENCE FROM INDIA
}

\author{
Manisha Shah \\ Bryce Millett Steinberg \\ Working Paper 21543 \\ http://www.nber.org/papers/w21543 \\ NATIONAL BUREAU OF ECONOMIC RESEARCH \\ 1050 Massachusetts Avenue \\ Cambridge, MA 02138 \\ September 2015
}

We would like to thank Natalie Bau, Eric Edmonds, Ed Glaeser, Nathan Hendren, Simon Jaeger, Emily Oster, Sarah Reber, Martin Rotemberg, and Jesse Shapiro for helpful advice. We thank Wilima Wadhwa for generously sharing the ASER data. The views expressed herein are those of the authors and do not necessarily reflect the views of the National Bureau of Economic Research.

NBER working papers are circulated for discussion and comment purposes. They have not been peerreviewed or been subject to the review by the NBER Board of Directors that accompanies official NBER publications.

(C) 2015 by Manisha Shah and Bryce Millett Steinberg. All rights reserved. Short sections of text, not to exceed two paragraphs, may be quoted without explicit permission provided that full credit, including (C) notice, is given to the source. 
Workfare and Human Capital Investment: Evidence from India

Manisha Shah and Bryce Millett Steinberg

NBER Working Paper No. 21543

September 2015

JEL No. I2,I38,J1,O12

\begin{abstract}
$\underline{\text { ABSTRACT }}$
We examine the effect of India's National Rural Employment Guarantee Scheme (NREGS), one of the largest workfare programs in the world, on human capital investment. Since NREGS increases labor demand, it could increase the opportunity cost of schooling, lowering human capital investment even as incomes increase. We exploit the staged rollout of the program across districts for causal identification. Using a household survey of test scores and schooling outcomes for approximately 2.5 million rural children in India, we show that each year of exposure to NREGS decreases school enrollment by 2 percentage points and math scores by $2 \%$ of a standard deviation amongst children aged 13-16. In addition, while the impacts of NREGS on human capital are similar for boys and girls, adolescent boys are primarily substituting into market work when they leave school while adolescent girls are substituting into unpaid domestic work. We find mixed results for younger children. We conclude that anti-poverty programs which raise wages could have the unintended effect of lowering human capital investment.
\end{abstract}

Manisha Shah

Department of Public Policy

University of California, Los Angeles

Luskin School of Public Affairs

3250 Public Affairs Building

Los Angeles, CA 90095-1656

and NBER

manishashah@ucla.edu

Bryce Millett Steinberg

Brown University

mbmillett@gmail.com 


\section{Introduction}

Workfare programs are an increasingly popular tool for alleviating poverty in developing countries. The World Bank alone supported at least 24 countries in mobilizing public works programs between 2007-2009 (Subbarao et al., 2013). Economists have studied the effects of such program on wages and private sector hiring. Ravallion (1987) and Basu et al. (2009) show that government hiring may crowd out private sector work and lead to a rise in equilibrium private sector wages. Recently various papers have shown that there has been an increase in rural wages in India due to workfare (Imbert and Papp, 2015; Berg et al., 2012; Azam, 2012).

In this paper we study the effect of India's National Rural Employment Guarantee Scheme (NREGS), one of the largest workfare programs in the world, on human capital outcomes of children aged 5-16. We measure human capital using a unique data set on test scores for children in rural India: the Annual Status of Education Report (ASER). ASER tests nearly 500,000 rural children per year, both in and out of school, on basic literacy and numeracy skills. To identify the causal effects of the program, we exploit the three-phase rollout. The program was introduced gradually throughout rural India starting with the poorest districts in early 2006 and extending to the entire country by 2008. We find that children score significantly lower on math and reading test scores once NREGS enters their district, and they are also significantly less likely to be currently enrolled and on track in school. These effects are strongest for the 13 to 16 year olds. In addition, each additional year of exposure to NREGS between the ages of 13 and 16 causes math scores to decrease by $2 \%$ of a standard deviation and enrollment rates to fall by two percentage points.

We show that increased labor demand due to NREGS is causing this decrease in human capital investment. NREGS increases the opportunity cost of time for families, which decreases time intensive human capital investments (as in Atkin (2012); Miller and Urdinola (2010); Shah and Steinberg (2013)). Consistent with this interpretation, the results are largely driven by children aged 13-16, who are old enough to substitute for adult labor but 
too young to be eligible for NREGS. Using data from the National Sample Survey, we show that when NREGS rolls out in a district, children ages 13-17 are 3 percentage points less likely to report school as their primary activity and 3 percentage points more likely to report productive work as their primary activity. We find that adolescent girls are more likely to substitute for their mothers in domestic work, while boys are more likely to work outside the home for pay.

The results for younger children are more mixed. We find little effect of overall exposure to NREGS for primary school children (aged 5-12). Additional years of exposure have a slightly negative (for children aged 9-12), or slightly positive (for children aged 5-8) effect on human capital investment. However, we do find that NREGA exposure from age 2-4 significantly improves test scores and the likelihood that these children will enrol and be on track in school when measured at age 5, suggesting the increased income due to NREGS might play a positive role for younger children in the household.

We then examine threats to identification and the extent to which pre-trends, endogenous rollout, and/or NREGS-induced selective migration could be driving the results. We show that these threats are unlikely to be driving the empirical results.

This research adds to a growing literature which attempts to document the general equilibrium price effects of poverty alleviation programs, both in the United States (Hastings and Washington, 2010; Rothstein, 2010) and in the developing world (Jayachandran et al., 2013; Angelucci and de Giorgi, 2009; Attanasio et al., 2011; Kablonski and Townsend, 2011). As far as we know, this is the first paper to document the possibility that a workfare program can lead to lower levels of human capital attainment using nationally representative test score data and school enrollment rates. Li and Sehkri (2013) examine the impact of NREGS on school enrollment numbers using school level data (District Information System for Education), and find that enrollment numbers decrease in treated districts. Dahl and Lochner (2012) find that the Earned Income Tax Credit increases child achievement in the United States. In addition, these findings could be of direct interest to policy makers considering 
using workfare as a means of poverty alleviation. Given the importance of education for economic growth, if these types of programs raise prevailing wages and cause older students to substitute toward work and away from school, lump sum grants or conditional cash transfers might be other options to consider.

\section{Background and Data}

\subsection{Background on NREGS}

Workfare programs have become a popular anti-poverty tool. First, they are self-targeting: only those who are willing to work for a low wage will receive the subsidy (Besley and Coate, 1992). Second, they prevent dependency as participants will turn away from public works as better labor market opportunities arise. Third, these programs may increase private sector wages as well, thereby further increasing incomes of the poor.

India's National Rural Employment Guarantee Act (NREGA), passed in 2005, provides a legal guarantee of up to 100 days of annual employment at the statutory minimum wage rate ${ }^{1}$ to rural households willing to supply manual labor on local public works in a financial year (Ministry of Rural Development, 2005). The Act mandates equality of wages for men and women and one-third of program beneficiaries to be women. It is operationalized through the National Rural Employment Guarantee Scheme which began in 2006 and has an annual budget of around Rs. 48,000 crores (approx. 9 billion dollars), amounting to more than 11\% of the 2011 Union budget expenditure. In 2009-10, approximately 53 million households across India were beneficiaries of NREGS (Dutta et al., 2012).

To obtain work on a project, interested adult members of a rural household must apply for a Job Card at the local Gram Panchayat. ${ }^{2}$ After due verification, the Gram Panchayat issues a Job Card, and the card should be issued within 15 days of application. The Job Card bears the photograph of all adult members of the household willing to work under NREGS

\footnotetext{
${ }^{1}$ The statutory minimum wage rate varies across states but it is approximately 2USD per day.

${ }^{2}$ The Gram Panchayat is the lowest level of administration in the Indian government comprising a group of villages.
} 
and is free of cost. Workers can apply for work at any time once they have a job card. The applicants must be assigned to a project within 15 days of submitting the application. If they are not given a job, they are eligible for unemployment compensation. Applicants have no choice over the project. The particular types of projects allowed under NREGS are typical rural employment projects such as road construction, earthworks related to irrigation and agriculture, and water conservation. The federal government bears the entire cost of wages of the workers and 75 percent of the cost of materials. The state governments bear the remaining 25 percent. In addition, state governments bear the cost of unemployment allowance payable when the state government cannot provide wage employment on time (Azam, 2012; Ministry of Rural Development, 2008). ${ }^{3}$

\subsection{Rollout of NREGS}

The National Rural Employment Guarantee Act was passed in 2005, and the scheme began to rollout in February 2006. Two hundred districts were given access to the program in February 2006. In April 2007, a further 130 districts were added, and in April 2008, the program became available in the remaining 270 districts. In this paper, we will refer to these groups of districts as "wave 1," "wave 2," and "wave 3," respectively. While the actual assignment mechanism to each wave is unknown, the government stated that an explicit goal of the roll out was to target the poorest districts first. However, it also guaranteed each state would receive at least one district in the first wave of the program. Zimmerman (2014) argues that based on the allocation of similar programs, it is likely that states were given slots to allocate to each wave based on poverty levels. Actual allocation was likely based on the government's own "backwardness rankings" which is a ranking of districts based on agricultural wages, percent of scheduled caste/scheduled tribe, and agricultural productivity (Planning Commission, 2003), though this ranking does not perfectly explain allocation to

\footnotetext{
${ }^{3}$ There is also a growing literature on corruption and leakage related to NREGS as well as potential interventions that might help improve these institutional problems (Niehaus and Sukhtankar, 2013; Niehaus et al., 2014; Afridi, 2008).
} 
each wave.

\subsection{Cognitive Testing and Schooling Data}

Every year since 2005, the NGO Pratham has implemented the Annual Status of Education Report (ASER), a survey on educational achievement of children aged 3-16 in India which reaches every rural district in the country. ${ }^{4}$ The math and literacy tests are administered to children ages 5-16 and so this is the age group we use in the analysis. ${ }^{5}$ We have yearly data on children for 2005-2009, giving us a sample size of approximately 2.5 million rural children. We have one round of pre-NREGS test score data (2005), three rounds of test score data during the rollout (2006-2008), and one round after the program has been rolled out throughout the country (2009).

The sample is a representative repeated cross section at the district level. The ASER data is unique in that its sample is extremely large and includes both in- and out-of-school children. Since cognitive tests are usually administered in schools, data on test scores is necessarily limited to the sample of children who are enrolled in school (and present when the test is given). However, ASER enumerators survey at the household on Sundays, when people generally do not work and children are not in school, and must return to households where children are not present at the time of the survey. Therefore, our sample includes children currently enrolled, children who have dropped out, and children who never enrolled. In Table 1 we describe the characteristics of the children in our sample as well as their test scores.

ASER surveyors ask each child four questions each in math and reading (in their native language). The four math questions are whether the child can recognize numbers 1-9, recognize numbers 10-99, subtract, and divide. The scores are coded as 1 if the child correctly

\footnotetext{
${ }^{4}$ This includes over 570 districts, 15,000 villages, 300,000 households and 700,000 children in a given year. ASER is the largest annual data collection effort with children in India. For more information on ASER, see http://www. asercentre.org/

${ }^{5}$ In 2005, only children aged 6-14 were tested. Our results are robust to restricting to these ages for all five years.
} 
answers the question, and 0 otherwise. We calculate a "math score" variable which ranges from $0-4$, and is the sum of the scores of the four numeracy questions. For example, if a child correctly recognizes numbers between 1-9 and 10-99, and correctly answers the subtraction question, but cannot correctly answer the division question, then that child's math score would be coded as 3. In 2006 and 2007, children were also asked two subtraction word problems. Thus, we also define "total math score" which includes these word problems in the years in which they were asked ${ }^{6}$. Total math score ranges from 0-6.

Each child was also asked to complete four reading tasks. The child is tested as to whether he/she can recognize letters, recognize words, read a paragraph, and read a story. We generate a total reading score that ranges from 0 to 4 depending on how many tasks the child can complete. The ASER dataset also includes information on whether the child is currently enrolled in school and the current grade of the child which we use as additional measures of schooling. ${ }^{7}$

\subsection{Labor and Employment Data}

To examine the impact of NREGS on schooling outcomes and work, we use the National Sample Survey (NSS) Rounds 60, 61, 62, 64 and 66 which was collected between 2003 and 2009 by the Government of India's Ministry of Statistics. This is a national labor and employment survey collected at the household level all over India, and we use data from all rural households in these surveys. Rounds 60 and 61 (2004 and 2005) are pre-rollout, round 62 straddles 2005 and 2006 but very few districts are sampled in 2006, round 64 is collected during the rollout (2007), and round 66 is collected after the rollout (2009). ${ }^{8}$

This dataset gives us measures of employment and schooling status at the individual level. The survey asks about the "primary activity" of each member of the household.

\footnotetext{
${ }^{6}$ Because we have year fixed effects in all regressions, the differential means in different years will not affect our analysis.

${ }^{7}$ More information on the ASER survey questions, sampling, and procedures can be found in the ASER data appendix.

${ }^{8}$ For the placebo analysis we also use round 55 (1999-2000) of the NSS data as it provides a longer time horizon for pre-trends to analyze.
} 
We define "domestic work" as individuals who report to attending domestic duties and/or engaging in free collection of goods (vegetables, roots, firewood, cattle feed, etc.), sewing, tailoring, weaving, etc. for household use; we define "works at home" as individuals who report to being self-employed and working in their household enterprise (either as an own account worker, an employer or as an unpaid family worker). We define "works outside of home" as someone who reports their status as a regular salaried/wage employee or as a paid casual laborer. An individual whose primary activity is going to school is defined as "attends school." 9

\section{$3 \quad$ Empirical Strategy}

Because NREGS was rolled out in three waves, we can compare districts before and after the program was in place while controlling for overall year and district effects. This strategy allows us to identify effects off the within-district timing of the rollout, rather than simply comparing districts in earlier and later waves.

We estimate the following regression:

$$
S_{i j t y}=\alpha+\beta_{1} \delta_{j t}+\gamma_{j}+\phi_{t}+\psi_{y}+\epsilon_{i j t y}
$$

where $S_{i j t y}$ is a schooling outcome variable (such as test score or enrollment status) for child $i$ in district $j$ in year $t$ who is age $y, \delta_{j t}$ is an indicator of whether district $j$ had NREGS in year $t, \gamma_{j}$ is a vector of district fixed effects, $\phi_{t}$ is a vector of year fixed effects, and $\psi_{y}$ is a vector of child age fixed effects. $\beta_{1}$ is our coefficient of interest, and it measures the effect of NREGS on the outcome variable $S$. Standard errors are clustered at the district level.

Identification relies on the assumption that in the absence of NREGS, the districts that received the program earlier and those that received the program later did not have system-

\footnotetext{
${ }^{9}$ Note that this question is asked slightly differently than the school enrollment question in the ASER data. ASER asks if each child is currently enrolled, and if so, in which type of school. NSS asks about the child's "primary activity." Thus, $94 \%$ of children in the ASER report being currently enrolled, while only $82 \%$ of children the same age report "attending school" as their primary activity.
} 
atically different time patterns in our outcome variables. We will rely on the assumption that the program was rolled out based on static characteristics of the districts, rather than underlying trends in school enrollment or child labor. This is similar to the method employed in Imbert and Papp (2015), which finds that NREGS increased private sector labor wages and rural incomes. We will investigate threats to identification explicitly in Section 6.

One might expect that children who were exposed to the program for a longer period of time experience larger effects. For example, in 2008, a 13 year old in wave 1 was exposed to NREGS longer than a 13 year old in wave 2. To test for this, we calculate "years of exposure" to NREGS for various cohort in each district. We calculate years of exposure for children aged 13-16, 9-12, 5-8, and 2-4, since increased wages can have differential effects at different ages (Shah and Steinberg, 2013). We estimate equation 1 where $\delta$ is now a vector which measures years of exposure to NREGS for each age group, rather than a dummy for whether or not the program has been rolled out. For the eldest three age categories, years of exposure ranges from 0-4 and for the 2-4 year olds, it ranges from 0-3. These regressions also contain additional fixed effects for year of birth (in addition to age and year fixed effects) to account for general cohort effects, which will be correlated with dosage.

\section{Results}

\subsection{ASER Main Results}

Table 2 shows our primary estimates of $\beta_{1}$ from equation 1 in the ASER data. Panel A shows results for the full sample of children, aged 5-16. In Panels B and C of Table 2, we separate children into two broad age groups: primary school age (5-12), and secondary school age (13-16). Columns 1-3 show the effect of NREGS on test scores while columns 4-5 show the estimates of the effect of NREGS on the probability that a child reports being enrolled in school and the effect of NREGS on a child's current grade

In Panel A, the results suggest that NREGA has a negative impact on total math score, currently enrolled, and current grade. The coefficient on total math score is -.08, and statisti- 
cally significant at the $1 \%$ level. This represents a $3 \%$ decrease from a mean of 3.02. Column 4 shows our estimate of the effect of NREGS on the probability that a child reports being enrolled in school. This coefficient is negative and statistically significant, and indicates that NREGS decreases the probability that a child is currently enrolled in school by .6 percentage points. Finally, column 5 shows estimates of the effect of NREGS on a child's current grade, which decreases by .05 years. Broadly, these results are consistent with NREGS reducing overall human capital investment, both on the intensive and extensive margins.

The results in Panel B for the older children are larger and statistically significant relative to the full sample. In fact, the negative impacts of NREGS are strongest for this age group. Enrollment rates for older children are dropping by almost a full percentage point when NREGS rolls out, which represents an $8 \%$ increase in the probability that these children are out of school. Current grade also decreases by .1 year when NREGS rolls out for this older group. In addition, total math score and reading test scores have negative and statistically significant coefficients, which indicates that learning, not just reported enrollment rates, are decreasing for these children.

The results in Panel $\mathrm{C}$ for the younger children are smaller and generally not statistically significant. Younger children are 0.4 percentage points less likely to be currently enrolled in school (from a mean of .96). Some coefficients are positive while others are negative. The magnitudes are small and none of the other coefficients on math/reading scores or current grade are statistically significant. Therefore, it seems the declines in observed human capital are primarily being driven primarily by the older children. ${ }^{10}$

\subsection{ASER Exposure Results}

Figure 1 shows the effect of each year of exposure from age 13-16 on school attendance and math scores. All coefficients are negative for both outcomes, and the effects get more

\footnotetext{
${ }^{10}$ In Table A1, we investigate the results by gender. Though all of the coefficients on the interaction of female and NREGS are negative, the only coefficient which is statistically significant is total math score. Overall, it seems that NREGS does not differentially affect human capital investment for girls and boys.
} 
negative as exposure increases, up to a 6 percentage point decrease in school enrollment and an almost .1 point decrease in math scores (10\% of a standard deviation) for 4 years of exposure. Figures 2 and 3 show the effect of exposure for each age group $(2-4,5-8,9-$ 12, and 13-16), estimated for all children aged 5-16, for math scores and school enrollment respectively. In these figures, though adolescent exposure to NREGS is clearly negative and decreasing, the effects at younger ages are quite different. For math scores in particular, the youngest age group (2-4) have markedly higher and increasing test scores with increased exposure to NREGS.

Table 3 reports the results from linear regressions of exposure to NREGS at each age group on all outcome variables. Again, exposure to NREGS has the largest negative impacts for the 13-16 year olds. Each year of exposure to NREGS during adolescence decreases school enrollment by 2 percentage points and math scores by $2 \%$ of a standard deviation. For total math score, the decrease is $10 \%$ of a standard deviation per year of exposure. This implies that by age 16, children who live in districts with NREGA for their entire adolescence score $8 \%$ of a standard deviation lower on math scores, and are 8 percentage points less likely to be in school. The results are less stark for exposure from age 9 to 12 . Negative magnitudes decrease and the majority of the coefficients are not statistically significant.

Again we see that for the younger children, the results are quite different. For each year of exposure from 2 to 4, NREGS increases math test scores by $5 \%$ of a standard deviation, and increases the likelihood that children are enrolled in school by almost 1 percentage point. This is consistent with Shah and Steinberg (2013) who find that increased wages in rural India are positively associated with human capital before age 5 (when the income effect is likely to dominate), but negatively associated with human capital at older ages.

\subsection{NSS Results}

We use the NSS data to corroborate the ASER human capital results. In addition, while the ASER results are informative about the reduced form effect of the program on human capital 
investment, we cannot learn whether children are substituting into productive work (as hypothesized) with the ASER data, since we have no information on their other activities. In Table 4, we show estimates of the effect of NREGS on children's reported "primary activity" using the NSS data for children aged 13-17 and 5-12. Columns 1 and 2 show the estimates of NREGS on whether the child reports that his or her primary activity is productive work versus attending school. We find that children ages 13-17 are three percentage points less likely to report attending school, and equally more likely to report working. This result is consistent with Islam and Sivasankaran (2014) who find an increase in time spent working outside the household for older children due to NREGS. The results for the younger children shown in Table 4 are neither economically meaningful nor statistically significant.

\section{Mechanisms}

We have shown that the introduction of NREGS caused a decrease in human capital investment amongst adolescents. In this section, we will outline the evidence for possible mechanisms. First, we will examine whether NREGS created a shift in labor demand that increased the opportunity cost of schooling. In addition, we will assess whether changes in the returns to schooling and/or decreased parental supervision could be driving the results.

Labor Demand From previous work, we know that NREGS caused an increase in labor demand and wages in the districts in which it was operational (Imbert and Papp, 2015; Zimmerman, 2014; Azam, 2012). Though work on NREGS projects was legally limited to those over the age of 18, this could have caused an increase in labor demand for adolescents in a few ways. First, there could have been some leakage in who was allowed to work for the program, with either adolescents lying about their age, or program administrators looking the other way. Second, the introduction of NREGS jobs could create additional jobs, such as selling tea or food to workers. Lastly, adolescents' labor could be substitutes for adults' labor, so that when adults begin working for NREGS, adolescents take their places doing 
household, farm, and domestic work. ${ }^{11}$

While we know from Table 4 that adolescents report increases in productive work at the onset of NREGS, in order to understand what is causing this, we look more closely at the shifts in labor amongst both parents and children. In Table 5 , we show estimates $\beta_{1}$ from Equation 1, where $S$ is one of primary activity categories, and $\delta$ is an indicator for the rollout of NREGS, estimated separately for fathers and mothers. ${ }^{12}$ Column 1 shows the effect of NREGS on working in a home enterprise (primarily farms), either as its head, an employer, or an unpaid family worker. We find that for fathers, this work is decreasing by 3 percentage points. Working outside the home increases for both mothers and fathers, though the increase is larger for fathers (5 percentage points versus 2 percentage points). Lastly, domestic work decreases for mothers by 3 percentage points. Overall this is consistent with mothers switching out of domestic work and into market work, either at home on the farm or outside in the market; while fathers are switching from working at home to working for wages in the market. ${ }^{13}$

In Table 6, we show our estimates of the impact of NREGS on primary activity, broken down by the same categories for children aged 13-17 with gender interactions. ${ }^{14}$ While we do not observe differences in the effects of NREGS on human capital investments by gender, we do observe differences in work type by gender. The pattern for boys is similar to that of adult men: they reduce working at home (and attending school) and increase the probability of working outside the home. Thus, for boys it looks as though they are either working directly for NREGS or in market jobs as substitutes for adult labor.

For girls, the results are quite different. Girls appear to be substituting almost entirely

\footnotetext{
${ }^{11}$ A related story is that when parents increase labor supply, they take their children with them to work. The children may have some marginal economic contribution, but really work is daycare (Edmonds and Pavcnik, 2005). We rule out this possibility since the main effects are coming from adolescents who would not require daycare from their parents.

${ }^{12}$ Male heads of household age 18-65 and female spouses of household heads aged 18-65, respectively.

${ }^{13}$ NSS does not directly ask households if they are working for NREGS until 2009, so we do not know whether the switch to outside work is into NREGS jobs or other paid work.

${ }^{14}$ In Appendix Table A5, we report these results for children age 5-12. We do not see similar effects for them. None of the results are statistically significant and most of the coefficients are close to zero.
} 
into domestic work when leaving school. Since mothers are substantially decreasing domestic work when NREGS becomes available, it is likely that these girls are substituting for their mothers' labor inside the household. We show these results graphically in Figures 4 and 5, respectively.

Returns to Schooling Since NREGS is a transfer program to the poor and largely uneducated, it can lower the average returns to schooling. If families are forward looking, they could reduce their schooling investment to adjust to the new, lower returns, which could explain our findings (Oster and Steinberg, 2013; Jensen, 2012). The increase in the agricultural wages due to NREGS is about 5 percent (Imbert and Papp, 2015; Berg et al., 2012; Azam, 2012). Returns to schooling in the developing world are estimated at $7-14 \%$ per year (Duflo, 2001; Card, 1999). If families expect the program to last for many years, it is possible that they chose to reduce their investment in human capital in expectation of lower returns. While we believe it is unlikely that parents believed the program would last for so long, we cannot rule out that the expectation of increased future wages, not just current increased wages, is driving decreases in school enrollment. ${ }^{15}$

Parental Supervision Another possible channel through which NREGS could impact human capital investment is if parents are integral in ensuring that their kids show up to school. If many children go from having mothers who work primarily in the home to mothers working outside the home, the lack of supervision could allow them to stay home from school without detection from their parents (Bursztyn and Coffman, 2012). In addition, perhaps now there is no one to get the child to and from school since both parents work outside the home. While it is certainly possible that some of this is going on, we think it is unlikely that this effect is driving our results. First, we primarily see the reduction in schooling for older children aged 13-17. These adolescents are almost surely not being walked to

\footnotetext{
${ }^{15}$ Since our estimates are identified off of the staged rollout, it would also have to be the case that expectations moved with the implementation of the program, rather than its announcement, since that did not vary across districts.
} 
school by their mothers and could probably skip school even with mothers at home. Second, we see commensurate increases in domestic work and work outside the home on surveys administered to the head of household. That is, parents are reporting that their children are not in school, but rather engaging in productive work. This seems incongruous with the idea that children are simply sneaking around when their parents are out of the house working.

\section{Threats to Identification}

\subsection{Pre-Trends}

Our identification relies on the assumption that in the absence of NREGS, the districts that received the program earlier and those that received the program later did not have systematically different time patterns in our outcome variables. ${ }^{16}$ While we cannot test this assumption directly, we can test whether it appears as though our results are being driven by the program or by underlying trends in eligible districts.

With the NSS data, we can analyze the trends in outcomes leading up to the passage of NREGS for early versus late access districts. In columns 2 and 3 of Table 7, we report results from a placebo regression in which we falsely assign early districts (waves 1 and 2) to have NREGS during 2004, and late districts (wave 3) to get the program in 2005 (in reality, no district received the program until 2006). ${ }^{17}$ Reassuringly, we find no effect of the program on primary activity before it began, and we can reject that the magnitudes are equal to our main effect size at the $5 \%$ level. This placebo treatment does not predict differences in probability of working or attending school.

For our analysis of the ASER data we cannot examine pre-trends because our data begins

\footnotetext{
${ }^{16}$ This is similar to the notion of "parallel trends" in differences-in-differences, except that since we have observations from more than two points in time, the timing effects need not be linear. In other words, conditional on district and year fixed effects, district-year observations that had access to NREGS differed only due to the program, not due to differential effects of year by wave.

${ }^{17} \mathrm{We}$ combine waves 1 and 2 in this analysis because in our main NSS results, we do not have much data from 2006. Thus, our identification comes from the differences between the districts in waves 1 and 2 and the districts in wave 3 . The results are robust to assigning treatment to districts in wave 1 in 2004 and wave 2 in 2005.
} 
in 2005, one year before the program is rolled out in wave 1 districts. Thus, we have no way of assessing the differential trends in enrollment early and late wave districts. However, we do have information on maternal education. Since mothers are an older cohort we can test whether maternal education is increasing over time differentially in early and late phase districts. If mothers' education, which should be fixed by 2005 when our analysis begins, is correlated with NREGS rollout, this would indicate that there are likely differential pretrends in school enrollment across waves. The results in column 1 of Table 7 show that the effect of NREGS on maternal education is small, positive and insignificant, suggesting that our results are not likely biased by differential pre-trends.

In addition, since we have five years of ASER data and three separate roll-out groups, we can re-estimate the main analysis from Table 2 including wave specific linear time trends. If our results are picking up gradual differences in outcomes over the five year period, then the waves trends should absorb this effect, and the coefficients should go to zero. However, if the impact is occurring due to the change from NREGS, the coefficients should remain the same. In Table A2, we show estimates of our coefficients from Table 2 with the addition

of wave-specific linear time trends. Reassuringly, the coefficients are all still negative and similar in magnitude, though some are less precisely estimated. Lastly in Table A3 we reestimate equation 1 (as in Table 2), including controls for rainfall this year and last year, since this can affect both wages and school enrollment. The coefficients in this estimation are very similar to those in Table 2.

\subsection{Endogenous Roll Out}

Early access to the NREGS program was not allocated randomly; the government explicitly set out to roll out the program to the neediest districts first. Each state was allocated a certain number of slots in each wave of the program, and was allowed to allocate those slots as it saw fit, though the process was supposed to be guided by the official backwardness rankings, based on agricultural productivity, percent scheduled caste and scheduled tribe, 
and agricultural wages (Zimmerman, 2014). The algorithm used to decide which districts actually received early access was not disclosed, and there was likely some discretion on the part of government officials.

If the endogenous choice of early districts was correlated with the levels of human capital investment, then district fixed effects would be enough to ensure that our results were not biased. If, however unlikely, state officials chose earlier districts based on the trend in educational investments and child labor, this could bias our results upward.

To test for this, we follow a simplified version of the methodology in Zimmerman (2014), in which we assign treatment status based solely on backwardness rankings from Planning Commission (2003) and the number of NREGS slots allocated to each state for each wave. That is, if Andhra Pradesh was allocated thirteen wave 1 slots, six wave 2 slots, and two wave 3 slots, we assign NREGS to the 13 most backward ranked districts in 2006, the next 6 lowest ranked districts in 2007, and the rest in 2008, regardless of when the district actually got access to NREGS. This can be thought of as an "intent to treat" estimate since some districts who would have received NREGS under this simpler assignment mechanism did not, presumably for political reasons.

Table A4 shows the results for our main specification using this alternative measure of treatment for the full sample (Panel A), the adolescents (Panel B), and the younger children (Panel C). The sample sizes in Table A4 are smaller as the Planning Commission only ranked 447 districts. Therefore, districts which are not ranked are not included in the analysis. The

results in Table A4 are similar to the main results in Table 2. The coefficients are similar in magnitude to our main results, and generally not statistically distinguishable from our main estimates in Table 2.

\subsection{Selective Migration}

If NREGS affected the migration patterns of adolescents, this could affect the sample of children who are available to be surveyed by both the ASER and the NSS. 
In general, migration rates in rural India are extremely low (Munshi and Rosenzweig, 2009; Topalova, 2005). In particular, migration between early and late NREGS districts is not a major concern since Indian Census data from 2001 estimates that rural interdistrict migration for employment was limited to $0.4 \%$ of all adults $18-60$. However, there is evidence that NREGS might decrease short-term migration from rural to urban areas for work (Imbert and Papp, 2014). This could bias the sample of children observed when enumerators survey the village and affect our analysis of test scores and school enrollment. It is important to note that to the extent that migrants are positively selected, we would expect this to bias our test score results downward, since these children would be more likely to show up in the ASER sample once NREGS has rolled out.

In addition, temporary migration for work is limited almost entirely to males in India. Women tend to stay in their parents' home until marriage, when they move to the home of their husband's family. Therefore, if migration is driving our results (presumably through negative selection of migrants), we should expect to observe this effect only in boys. However, our results show that adolescent girls experience similar reduction in test scores, enrollment rates, and grade, as well as commensurate increases in productive work.

Perhaps most importantly, our results are simply too large to be explained by migration. Imbert and Papp (2014) finds that NREGS decreased migration from rural to urban areas by .5 percentage points among adults in the NSS. Using the same data, we show a decrease in enrollment of 3 percentage points due to NREGS. Assuming that the migration rate is the same among adolescents, and that all of the temporary migrants would otherwise be in school, this could explain at most $17 \%$ of the decrease in enrollment we find in the NSS sample and $55 \%$ in the ASER sample. In short, even under the most generous assumptions, changes in migration are simply not large enough to explain the decreases in school enrollment found in this paper. 


\section{Discussion and Conclusion}

This paper examines the effect of NREGS, a large workfare program in India, on school enrollment, test scores, and child labor. We show that NREGS decreased human capital investment, primarily for children over the age of twelve, and that this was likely caused by boys responding to the increase in labor demand by working outside the home, and girls substituting for their mothers in domestic work. Each year of exposure to NREGS decreases school enrollment by 2 percentage points and math scores by $2 \%$ of a standard deviation amongst children aged 13-16. Our estimates suggest that NREGS may have caused anywhere from 650,000 to 2.5 million adolescents to leave school prematurely. ${ }^{18}$ These results are consistent with earlier findings on the effect of wages on human capital investment in India (Shah and Steinberg, 2013), though the current results may be of more interest to policy makers, since the wage increase is being caused by a government anti-poverty effort.

It is worth noting that NREGS was designed with the intent to both lower poverty and increase female empowerment by increasing women's labor force participation and earnings potential. These results suggest, however, that it could be unintentionally decreasing the future earnings potential of some of its beneficiaries by inducing them to drop out of school earlier than they otherwise would have. This is especially true for girls, who, rather than gaining market experience and their own earnings like their male counterparts are substituting for their mothers at home. Based on our estimates, for every 20 women induced into the labor force by NREGS, between 1.2 and 4 adolescent girls may have dropped out of school, nearly all of them to go into full-time domestic work in their parents' homes. ${ }^{19}$

It is important to note that this analysis represents the effect of NREGS on one particular outcome that may be of interest to policy makers (human capital investment). While

\footnotetext{
${ }^{18}$ Numbers are based on estimates of decreased enrollment from .9-3 percentage points, and the total population of rural Indians between the age of 13-16 (for ASER estimates) and 13-17 (for NSS estimates) from the 2011 Census of India.

${ }^{19}$ We note there may be significant heterogeneity across India and that we are reporting all India averages. For example, in the state of Andhra Pradesh, Afridi et al. (2013) find that mothers participation in the labor force due to NREGS results in almost two additional months of attendance in a school year by her children and reduces the gap between a childs actual and ideal grade by more than a quarter.
} 
we would argue that this is quite an important outcome for economic growth, we are not measuring any of the potential benefits that the program provides in terms of consumption, protection against income shocks, or any number of other outcomes. Thus, we are not in a position to measure the overall welfare impact of this particular anti-poverty program.

Rather, the takeaway from these results is that social programs have price effects, and that these price effects can have very real consequences. If workfare programs raise prevailing wages and cause older students to substitute toward work and away from school, lump sum grants or conditional cash transfers might be alternative options to consider. ${ }^{20}$ Ultimately, it is important to understand the price effects so that social programs can be designed in order to maximize their potential to increase economic growth and alleviate poverty.

\footnotetext{
${ }^{20}$ In a recent working paper, Alik-Lagrange and Ravallion (2015) shows that a basic income guarantee dominates net workfare earnings in terms of the impact on poverty for a given budgetary outlay, once expected welfare losses from work requirements are incorporated into the model.
} 


\section{References}

Afridi, Farzana, "Can Community Monitoring Improve the Accountability of Public Officials," Economic and Political Weekly, October 2008.

_, Abhiroop Mukhopadhyay, and Soham Sahoo, "Female Labor Force Participation and Child Education in India: Evidence from the National Rural Employment Guarantee Scheme," 2013. mimeo.

Alik-Lagrange, Arthur and Martin Ravallion, "Inconsistent Policy Evaluation: A Case Study for a Large Workfare Program," March 2015. NBER Working Paper No. 21041.

Angelucci, Manuela and Giacomo de Giorgi, "Indirect Effects of an Aid Program: How Do Cash Transfers Affect Ineligibles' Consumption?," American Economic Review, 2009, 99 (1), 486-508.

Atkin, David, "Endogenous Skill Acquisition and Export Manufacturing in Mexico," July 2012. Working Paper.

Attanasio, Orazio P., Costas Meghir, and Ana Santiago, "Education Choices in Mexico: Using a Structural Model and a Randomized Experiment to Evaluate PROGRESA," Review of Economic Studies, 2011, 79, 37-66.

Azam, Mehtabul, "The Impact of Indian Job Guarantee Scheme on Labor Market Outcomes: Evidence from a Natural Experiment," 2012. IZA Working Paper 6548.

Basu, Arnab K., Nancy H. Chau, and Ravi Kanbur, "A Theory of Employment Guarantees: Contestability Credibility and Distributional Concerns," Journal of Public Economics, 2009, 93 (3-4), 482497.

Berg, Erlend, Sambit Bhattacharyya, Rajasekhar Durgam, and Manjula Ramachandra, "Can Rural Public Works Affect Agricultural Wages? Evidence from lndia," May 2012. CSAE Working Paper.

Besley, Timothy and Stephen Coate, "Workfare versus Welfare: Incentive Arguments for Work Requirements in Poverty-Alleviation Programs," American Economic Review, 1992, 82 (1), 249-261.

Bursztyn, Leonardo and Lucas C Coffman, "The Schooling Decision: Family preferences, Intergenerational Conflict, and Moral Hazard in the Brazilian Favelas," Journal of Political Economy, 2012, 120 (3), 359-397.

Card, David, "The Causal Effect of Education on Earnings," Handbook of labor economics, 1999, 3, 1801-1863.

Dahl, Gordon B. and Lance Lochner, "The Effect of Family Income on Child Achievement: Evidence from the Earned Income Tax Credit," American Economic Review, August 2012, 102 (5).

Duflo, Esther, "Schooling and Labor Market Consequences of School Construction in Indonesia: Evidence from an Unusual Policy Experiment," The American Economic Review, 2001, 91 (4), 795. 
Dutta, Puja, Rinku Murgai, Martin Ravallion, and Dominique van de Walle, "Does Indias Employment Guarantee Scheme Guarantee Employment?," Economic $\&$ Political Weekly, April 2012, xlviI (16), 55-64.

Edmonds, Eric V. and Nina Pavcnik, "Child Labor in the Global Economy," Journal of Economic Perspectives, 2005, 19 (1), 199-220.

Hastings, Justine and Ebonya Washington, "The First of the Month Effect: Consumer Behavior and Store Responses," American Economic Journal: Economic Policy, 2010, 2, 142-162.

Imbert, Clement and John Papp, "Short-term Migration, Rural Workfare Programs and Urban Labor Markets: Evidence from India," January 2014. mimeo.

_ and _, "Labor Market Effects of Social Programs: Evidence from India's Employment Guarantee," American Economic Journal: Applied Economics, April 2015, 7 (2).

Islam, Mahnaz and Anitha Sivasankaran, "How does Child Labor respond to changes in Adult Work Opportunities? Evidence from NREGA," 2014. mimeo.

Jayachandran, Seema, Jesse M. Cunha, and Giacomo de Giorgi, "The Price Effects of Cash Versus In-Kind Transfers," 2013.

Jensen, Robert, "Do Labor Market Opportunities Affect Young Women's Work and Family Decisions? Experimental Evidence from India," The Quarterly Journal of Economics, 2012, 127 (2), 753-792.

Kablonski, Joseph P. and Robert M. Townsend, "A Structural Evaluation of a Large-Scale Quasi-Experimental Microfinance Initiative," Econometrica, 2011, 79 (5), 1357-1406.

Li, Tianshu and Sheetal Sehkri, "The Unintended Consequences of Employment Based Safety Net Programs," 2013. mimeo.

Miller, Grant and B. Piedad Urdinola, "Cyclicality, Mortality, and the Value of Time: The Case of Coffee Price Fluctuations and Child Survival in Colombia," Journal of Political Economy, 2010, 118 (1).

Ministry of Rural Development, "Mahatma Gandhi National Rural Employment Guarantee Act (Mahatma Gandhi NREGA)," Technical Report, Ministry of Rural Development, Government of India 2005.

_ , "The National Rural Employment Guarantee Act 2005 (NREGA)," Technical Report, Ministry of Rural Development, Government of India 2008.

Munshi, Kaivan and Mark Rosenzweig, "Why is Mobility in India so Low? Social Insurance, Inequality and Growth," 2009. NBER Working Paper No. 14850.

Niehaus, Paul and Sandip Sukhtankar, "The Marginal Rate of Corruption in Public Programs: Evidence from India," Journal of Public Economics, August 2013, 104, 52-64.

_, Karthik Muralidharan, and Sandip Sukhtankar, "Building State Capacity: Evidence from Biometric Smartcards in India," 2014. NBER Working Paper w19999. 
Oster, Emily and Bryce Millett Steinberg, "Do IT Service Centers Promote School Enrollment? Evidence from India," Journal of Development Economics, 2013, 104, 123-135.

Planning Commission, "Report of the Task Force on "Identification of Districts for Wage and Self employment programmes"," Technical Report New Delhi 2003.

Ravallion, Martin, "Market Responses to Anti-Hunger Policies: Effects on Wages, Prices and Employment," 1987. WIDER Working Paper 28.

Rothstein, Jesse, "Is the EITC as Good as an NIT? Conditional Cash Transfers and Tax Incidence," American Economic Journal: Economic Policy, 2010, 2, 177-208.

Shah, Manisha and Bryce Millett Steinberg, "Drought of Opportunities: Contemporaneous and Long Term Impacts of Rainfall Shocks on Human Capital," June 2013. NBER Working Paper 19140.

Subbarao, Kalanidhi, Carlo del Ninno, Colin Andrews, and Claudia Rodriguez-Alas, "Public Works as a Safety Net-Design, Evidence, and Implementation," Technical Report, World Bank 2013.

Topalova, Petia, "Trade Liberalization, Poverty, and Inequality: Evidence from Indian Districts," 2005. NBER Working Paper No. 11614.

Zimmerman, Laura, "Why Guarantee Employment? Evidence from a Large Indian Public-Works Program," 2014. mimeo. 


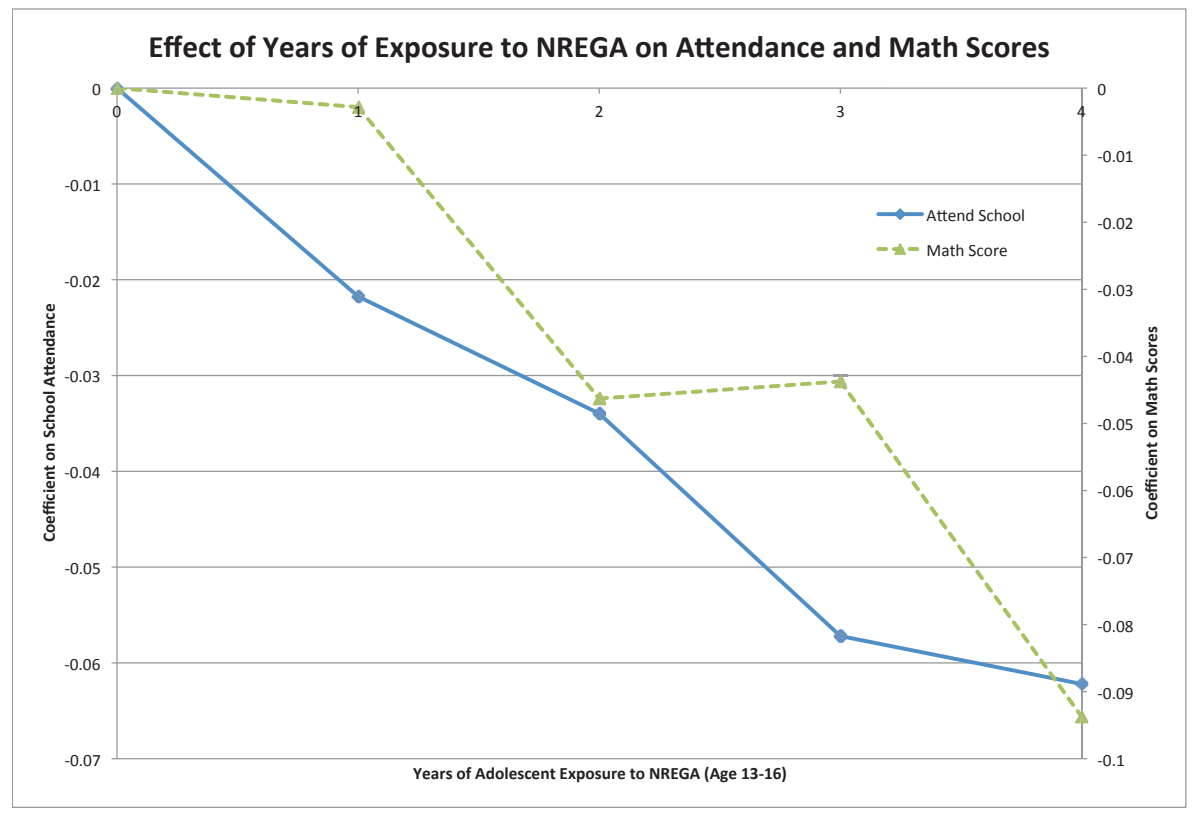

Source: ASER (2005-2009)

Notes: This figure shows estimates of $\beta_{1}$ for the effect of each year of exposure to NREGS on math score in the ASER data, for children aged 13-16. The estimating equation is similar to Equation (1) where $\delta$ is a vector of dummy variables for each year of exposure to NREGS (0-4) between the ages of 13 and 16, where "exposure" is defined as a year in which NREGA has rolled out to the child's district, and the child is between 13 and 16. All regressions contain fixed effects for child age, year of birth, year of survey, and district.

Figure 1: Effect of Years of Adolescent Exposure of NREGS Math Test Scores and School Enrollment 


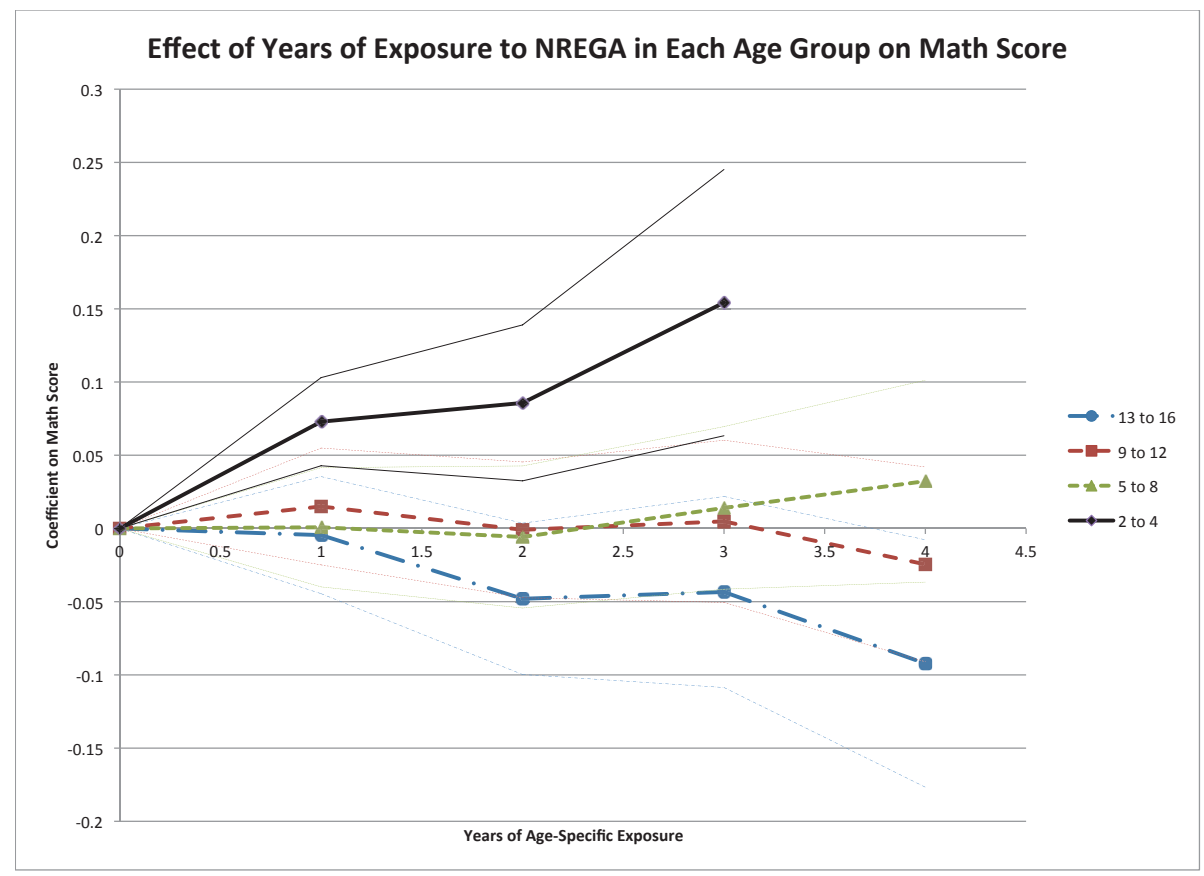

Source: ASER (2005-2009)

Notes: This figure shows estimates of $\beta_{1}$ for the effect of each year of exposure to NREGS on math score in the ASER data, for children aged 5-16. The estimating equation is similar to Equation (1) where $\delta$ is a vector of dummy variables for each year of exposure to NREGS (0-4) in each age group, where "exposure" is defined as a year in which NREGA has rolled out to the child's district, and the child is in the given age group. All regressions contain fixed effects for child age, year of birth, year of survey, and district.

Figure 2: Effect of Years of Exposure of NREGS by Age on Test Scores 


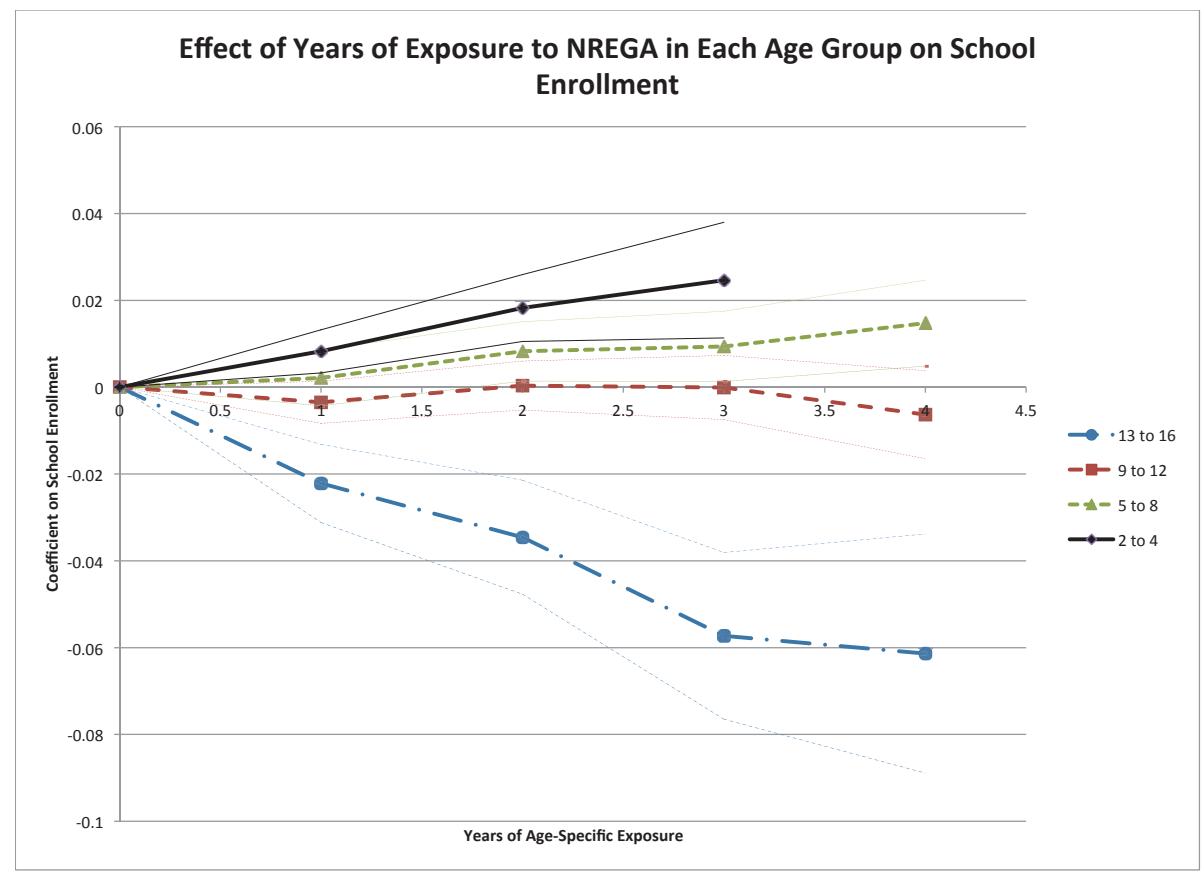

Source: ASER (2005-2009)

Notes: This figure shows estimates of $\beta_{1}$ for the effect of each year of exposure to NREGS on school enrollment in the ASER data, for children aged 5-16. The estimating equation is similar to Equation (1) where $\delta$ is a vector of dummy variables for each year of exposure to NREGS (0-4) in each age group, where "exposure" is defined as a year in which NREGA has rolled out to the child's district, and the child is in the given age group. All regressions contain fixed effects for child age, year of birth, year of survey, and district.

Figure 3: Effect of Years of Exposure of NREGS by Age on School Enrollment 


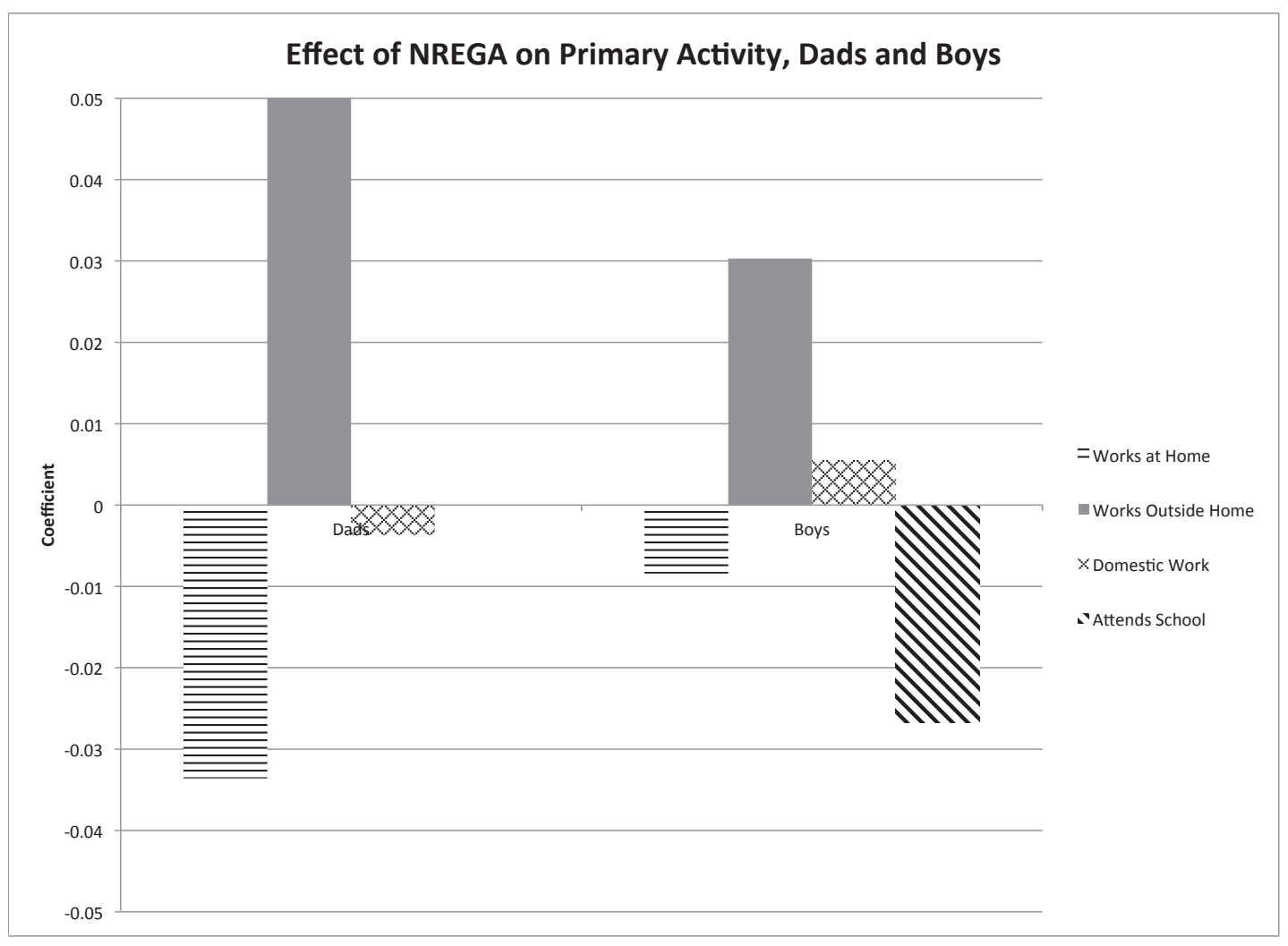

Source: NSS 2003-2009 (rounds 60, 61, 62, 64, 66)

Notes: This figure shows estimates of the coefficients from Table 5 (Panel B) and Table 6 (Panel C) represented graphically. The coefficients are estimates of $\beta_{1}$ from the OLS estimation of Equation (1) where $S$ is a dummy for each specified primary activity (market work at home, market work outside the home, domestic work, or attends school), and $\delta$ is a dummy variable for whether NREGS has rolled out in the respondent's district and year. All regressions contain fixed effects for district and year. "Fathers" are defined as males between the age of 18 and 65 who report their household status as "head of household." "Boys" are defined as males between the ages of 13 and 17.

Figure 4: Effect of NREGS on Primary Activity, Dads and Boys 


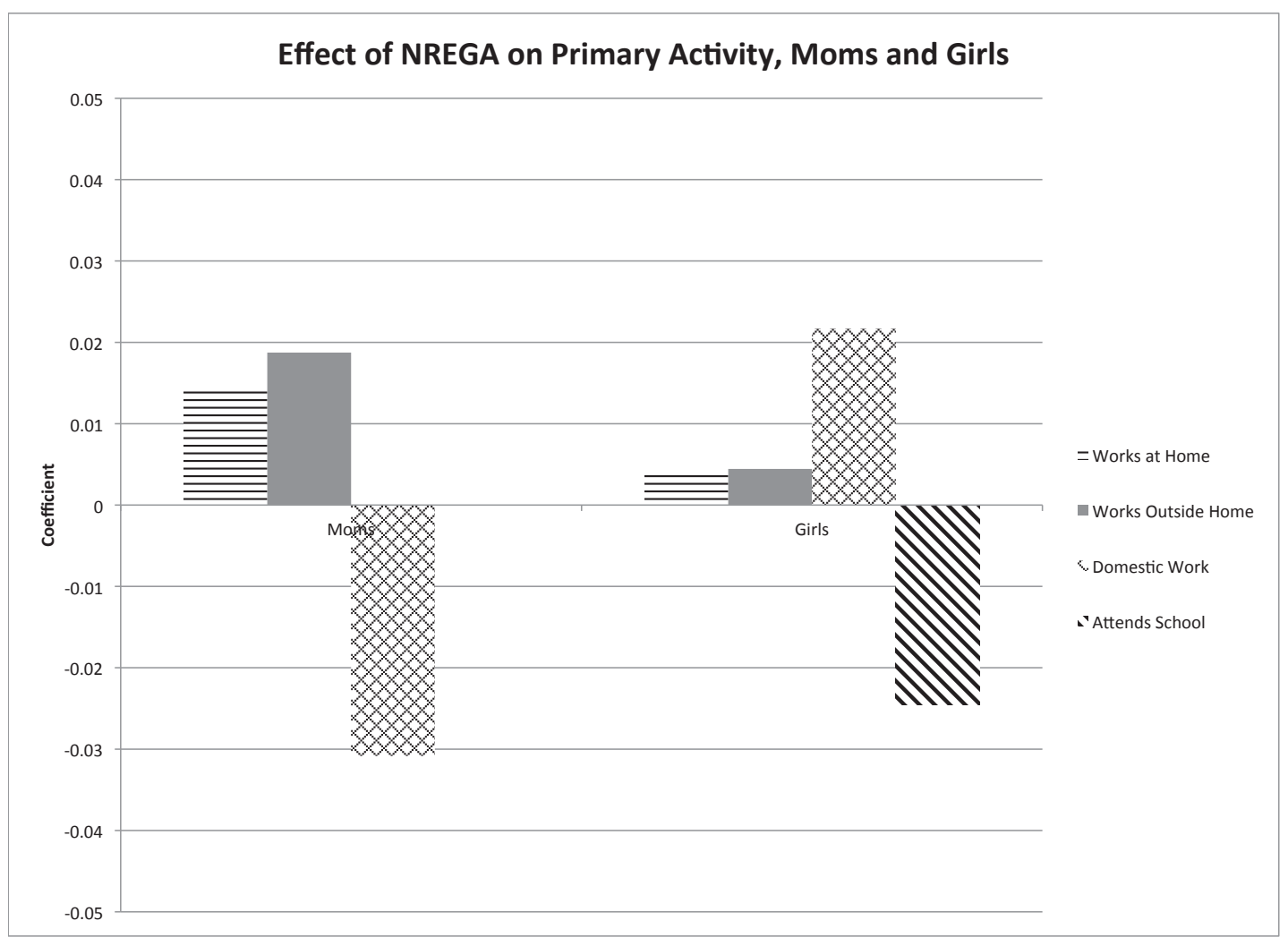

Source: NSS 2003-2009 (rounds 60, 61, 62, 64, 66)

Notes: This figure shows the coefficients from Table 5 (Panel A) and Table 6 (Panel B) represented graphically. The coefficients are estimates of $\beta_{1}$ from the OLS estimation of Equation (1) where $S$ is a dummy for each specified primary activity (market work at home, market work outside the home, domestic work, or attends school), and $\delta$ is a dummy variable for whether NREGS has rolled out in the respondent's district and year. All regressions contain fixed effects for district and year. "Mothers" are defined as females between the age of 18 and 65 who report their household status as "spouse of head of household". "Girls" are defined as females between the ages of 13 and 17.

Figure 5: Effect of NREGS on Primary Activity, Moms and Girls 
Table 1: Summary Statistics

\begin{tabular}{lccc}
\hline \multicolumn{5}{c}{ ASER Summary Statistics (ages 5-16) } \\
\hline \hline & Mean & Std. Dev. & Observations \\
Age & 10.29 & 3.10 & $2,564,476$ \\
Female & .45 & .49 & $2,564,476$ \\
Math Score & 2.61 & 1.31 & $2,564,476$ \\
Total Math Score (with Word Problems) & 3.02 & 1.77 & $2,564,476$ \\
Reading Score & 2.71 & 1.41 & $2,578,670$ \\
Currently Enrolled & .94 & .25 & $2,661,811$ \\
Current Grade & 4.59 & 2.84 & $2,483,281$ \\
\hline \multicolumn{5}{c}{ ASER Summary Statistics (ages $13-16)$} & \\
\hline \hline & Mean & Std. Dev. & Observations \\
Age & 14.3 & 1.08 & 689,938 \\
Female & .45 & .50 & 689,938 \\
Math Score & 3.43 & .98 & 689,938 \\
Total Math Score (with Word Problems) & 4.12 & 1.53 & 689,938 \\
Reading Score & 3.57 & .973 & 692,125 \\
Currently Enrolled & .87 & .34 & 732,543 \\
Current Grade & 7.66 & 2.54 & 647,604 \\
\hline \multicolumn{5}{l}{ Age } & & & \\
\hline \hline
\end{tabular}

Source: ASER (2005-2009) and NSS (rounds 60, 61, 62, 64, and 66).

Notes: This table contains summary statistics for the outcome and control variables in this paper. 
Table 2: Effect of NREGS on Test Scores and Schooling

\begin{tabular}{|c|c|c|c|c|c|}
\hline Dep. Var: & $\begin{array}{l}\text { Math } \\
\text { Score }\end{array}$ & $\begin{array}{l}\text { Total Math } \\
\text { Score }\end{array}$ & $\begin{array}{l}\text { Reading } \\
\text { Score }\end{array}$ & $\begin{array}{l}\text { Currently } \\
\text { Enrolled }\end{array}$ & $\begin{array}{l}\text { Current } \\
\text { Grade }\end{array}$ \\
\hline & \multicolumn{5}{|c|}{ Panel A: Full Sample } \\
\hline NREGS & $\begin{array}{l}.0006 \\
(.02)\end{array}$ & $\begin{array}{l}-.08 \\
(.03)^{* * *}\end{array}$ & $\begin{array}{l}.003 \\
(.02)\end{array}$ & $\begin{array}{l}.006 \\
(.003)^{* *}\end{array}$ & $\begin{array}{l}-.05 \\
(.02)^{* *}\end{array}$ \\
\hline Observations & $2,564,476$ & $2,564,476$ & $2,578,670$ & $2,661,811$ & $2,483,281$ \\
\hline \multirow[t]{2}{*}{ Mean DV } & 2.61 & 3.02 & 2.71 & .94 & 4.60 \\
\hline & \multicolumn{5}{|c|}{ Panel B: Ages 13-16 } \\
\hline NREGS & $\begin{array}{l}-.03 \\
(.02)\end{array}$ & $\begin{array}{l}-.13 \\
(.03)^{* * *}\end{array}$ & $\begin{array}{l}-.04 \\
(.02)^{*}\end{array}$ & $\begin{array}{l}-.009 \\
(.005)^{*}\end{array}$ & $\begin{array}{l}-.1 \\
(.04)^{* *}\end{array}$ \\
\hline Observations & 689,938 & 689,938 & 692,125 & 732,543 & 647,604 \\
\hline \multirow[t]{2}{*}{ Mean DV } & 3.43 & 4.12 & 3.57 & .87 & 7.66 \\
\hline & \multicolumn{5}{|c|}{$\begin{array}{l}\text { Panel C: Ages 5-12 } \\
\end{array}$} \\
\hline NREGS & $\begin{array}{l}.008 \\
(.02)\end{array}$ & $\begin{array}{l}.05 \\
. .03)\end{array}$ & $\begin{array}{l}.02 \\
(.02)\end{array}$ & $\begin{array}{l}-.004 \\
(.002)^{*}\end{array}$ & $\begin{array}{l}-.02 \\
(.02)\end{array}$ \\
\hline Observations & $1,874,538$ & $1,874,538$ & $1,886,545$ & $1,929,268$ & $1,835,677$ \\
\hline Mean DV & 2.32 & 2.61 & 2.40 & .96 & 3.51 \\
\hline District FEs & YES & YES & YES & YES & YES \\
\hline Year FEs & YES & YES & YES & YES & YES \\
\hline Age FEs & YES & YES & YES & YES & YES \\
\hline
\end{tabular}

Source: ASER (2005-2009)

Notes: This table reports estimates of $\beta_{1}$, the effect of NREGS on math and reading test scores and schooling outcomes from the ASER data. The coefficients are estimates of $\beta_{1}$ from the OLS estimation of Equation (1) where $S$ is the listed dependent variable, and $\delta$ is a dummy variable for whether NREGS has rolled out in the respondent's district and year. Math score ranges from 0-4, total math score ranges from 0-6, and read score ranges from 0-4. All panels include year, child age, and district fixed effects. Standard errors clustered at the district level are reported in parentheses. ${ }^{* * *}$ indicates significance at $1 \%$ level, $* *$ at $5 \%$ level, $*$ at $10 \%$ level. 
Table 3: Effect of NREGS on Test Scores and Schooling, by Years of Exposure

\begin{tabular}{lccccc}
\hline Dep. Var: & $\begin{array}{c}\text { Math } \\
\text { Score }\end{array}$ & $\begin{array}{c}\text { Total Math } \\
\text { Score }\end{array}$ & $\begin{array}{c}\text { Reading } \\
\text { Score }\end{array}$ & $\begin{array}{c}\text { Currently } \\
\text { Enrolled }\end{array}$ & $\begin{array}{c}\text { Current } \\
\text { Grade }\end{array}$ \\
\hline Exposure (ages 13-16) & -.02 & -.19 & .009 & -.02 & -.31 \\
& $(.01)^{* *}$ & $(.02)^{* * *}$ & $(.01)$ & $(.003)^{* * *}$ & $(.03)^{* * *}$ \\
Exposure (ages 9-12) & -.004 & -.02 & .003 & .0004 & -.05 \\
& $(.008)$ & $(.01)^{*}$ & $(.008)$ & $(.001)$ & $(.009)^{* * *}$ \\
Exposure (ages 5-8) & .001 & .01 & -.007 & .004 & .03 \\
& $(.008)$ & $(.01)$ & $(.009)$ & $(.001)^{* * *}$ & $(.01)^{* * *}$ \\
Exposure (ages 2-4) & .05 & .001 & .04 & .009 & .08 \\
& $(.01)^{* * *}$ & $(.02)$ & $(.01)^{* * *}$ & $(.002)^{* * *}$ & $(.02)^{* * *}$ \\
Observations & $2,564,476$ & $2,565,476$ & $2,578,670$ & $2,661,811$ & $2,483,281$ \\
Mean DV & 2.61 & 3.02 & 2.71 & .94 & 4.60 \\
\hline \hline District FEs & YES & YES & YES & YES & YES \\
Year FEs & YES & YES & YES & YES & YES \\
Age FEs & YES & YES & YES & YES & YES \\
Year of Birth FEs & YES & YES & YES & YES & YES \\
\hline
\end{tabular}

Source: ASER (2005-2009)

Notes: This table shows estimates of the years of exposure of NREGS on math and reading test scores and schooling outcomes from the ASER data. The coefficients are estimates of $\beta_{1}$ from the OLS estimation of Equation (1) where $S$ is the listed dependent variable, and $\delta$ is years of exposure for each age group and ranges from $0-4$. Math score ranges from $0-4$, total math score ranges from 0-6, and read score ranges from 0-4. All panels include child age, year of birth, year child age, and district fixed effects. Standard errors clustered at the district level are reported in parentheses. $* * *$ indicates significance at $1 \%$ level, ** at $5 \%$ level, * at $10 \%$ level.

Table 4: Effect of NREGS on Working and School Attendance

\begin{tabular}{lcc|cc}
\hline & \multicolumn{2}{c}{ Ages 13-17 } & \multicolumn{2}{c}{ Ages 5-12 } \\
Dep. Var: & Works & Attends School & Works & Attends School \\
\hline \hline NREGS & .03 & -.03 & .003 & .002 \\
& $(.008)^{* * *}$ & $(.009)^{* * *}$ & $(.003)$ & $(.007)$ \\
Observations & 146,926 & 146,926 & 254,982 & 254,982 \\
Mean of DV & .25 & .70 & .03 & .85 \\
\hline \hline District FEs & YES & YES & YES & YES \\
Year FEs & YES & YES & YES & YES \\
Age FEs & YES & YES & YES & YES \\
\hline
\end{tabular}

Source: NSS 2003-2009 (rounds 60,61, 62, 64, 66)

Notes: This table reports estimates of $\beta_{1}$, the effect of NREGS on children who report their "primary activity" as work or school attendance. The coefficients are from the OLS estimation of Equation (1) where $S$ is a dummy for each specified primary activity and $\delta$ is a dummy variable for whether NREGS has rolled out in the respondent's district and year. Standard errors clustered at the district are reported in parentheses. ${ }^{* * *}$ indicates significance at $1 \%$ level, ${ }^{* *}$ at $5 \%$ level, ${ }^{*}$ at $10 \%$ level. 
Table 5: Effect of NREGS on Parents' Primary Activities

\begin{tabular}{lccc}
\hline \multicolumn{4}{c}{ Panel A: Mothers } \\
\hline \hline Dep. Var: & Works at & Works outside & Domestic \\
& Home & Home & Work \\
\hline NREGS & .01 & .02 & -.03 \\
& $(.01)$ & $(.007)^{* * *}$ & $(.01)^{* *}$ \\
Observations & 228,747 & 228,747 & 228,747 \\
Mean of DV & .24 & .16 & .58 \\
\hline \multicolumn{4}{c}{ Panel B: Fathers } \\
\hline \hline Dep. Var: & Works at & Works outside & Domestic \\
& Home & Home & Work \\
\hline NREGS & -.03 & .05 & -.004 \\
& $(.01)^{* * *}$ & $(.01)^{* * *}$ & $(.005)$ \\
Observations & 235,086 & 235,086 & 235,086 \\
Mean of DV & .53 & .40 & .02 \\
\hline District FEs & YES & YES & YES \\
Year FEs & YES & YES & YES \\
Age FEs & YES & YES & YES \\
\hline
\end{tabular}

Source: NSS 2003-2009 (rounds 60,61, 62, 64, 66)

Notes: This table reports estimates of $\beta_{1}$, the effect of NREGS on primary activities of parents using the NSS 2003-2009 (rounds 60,61, 62, 64, 66). The coefficients are from the OLS estimation of Equation (1) where $S$ is a dummy for each specified primary activity (market work at home, market work outside the home, or domestic work), and $\delta$ is a dummy variable for whether NREGS has rolled out in the respondent's district and year. Panel A restricts to "mothers," defined as female spouses of heads of household, ages 18-64. Panel B restricts to "fathers", defined as male heads of household ages 18-64. Standard errors clustered at the district level are reported in parentheses. ${ }^{* * *}$ indicates significance at $1 \%$ level, ${ }^{* *}$ at $5 \%$ level, $*$ at $10 \%$ level. 
Table 6: Children's Primary Activity (Ages 13-17)

\begin{tabular}{lcccc}
\hline Dep. Var: & $\begin{array}{c}\text { Works at } \\
\text { Home }\end{array}$ & $\begin{array}{c}\text { Works outside } \\
\text { Home }\end{array}$ & $\begin{array}{c}\text { Domestic } \\
\text { Work }\end{array}$ & $\begin{array}{c}\text { Attends } \\
\text { School }\end{array}$ \\
\hline NREGS & -.008 & .03 & .006 & -.03 \\
& $(.007)$ & $(.007)^{* * *}$ & $(.003)^{*}$ & $(.01)^{* * *}$ \\
NREGS X Female & .01 & -.03 & .02 & .002 \\
& $(.008)$ & $(.008)^{* * *}$ & $(.009)^{*}$ & $(.01)$ \\
Observations & 146,926 & 146,926 & 146,926 & 146,926 \\
\hline Mean of DV (Boys) & .08 & .08 & .01 & .77 \\
Mean of DV (Girls) & .05 & .04 & .19 & .69 \\
\hline \hline District X Female FEs & YES & YES & YES & YES \\
Year X Female FEs & YES & YES & YES & YES \\
Age X Female FEs & YES & YES & YES & YES \\
\hline
\end{tabular}

Source: NSS 2003-2009 (rounds 60, 61, 62, 64, 66)

Notes: This table reports estimates of $\beta_{1}$, the effect of NREGS on primary activities of adolescents using the NSS. The coefficients are from the OLS estimation of Equation (1) where $S$ is a dummy for each specified primary activity (market work at home, market work outside the home, domestic work, or school attendance), and $\delta$ is a dummy variable for whether NREGS has rolled out in the respondent's district and year. Standard errors clustered at the district level are reported in parentheses. $* * *$ indicates significance at $1 \%$ level, ${ }^{* *}$ at $5 \%$ level, ${ }^{*}$ at $10 \%$ level.

Table 7: Testing for Pre-Trends and Placebo Analysis

\begin{tabular}{lc|cc}
\hline & Ages 25+ & \multicolumn{2}{c}{ Ages 13-17 } \\
Years: & ASER (2005-2009) & NSS Placebo (1999-2005) \\
\hline \hline Dep. Var: & Mother & Works & Attends School \\
& Attended School & & \\
\hline NREGS & .009 & -.001 & .003 \\
& $(.006)$ & $(.01)$ & $(.01)$ \\
Observations & $2,332,955$ & 115,553 & 115,553 \\
Mean of DV & .45 & .29 & .66 \\
\hline \hline District FEs & YES & YES & YES \\
Year FEs & YES & YES & YES \\
\hline
\end{tabular}

Source: ASER 2005-2009 (Column 1), NSS 1999-2005 (rounds 55, 60, 61, 62) (Columns 2 and 3)

Notes: This table shows estimates of the effect of NREGS on maternal education using ASER data from 2005-2009. In Column 1 , the coefficients are from the OLS estimation of Equation (1) where $S$ is a dummy variable which is equal to one if the mother has had any formal schooling, and zero otherwise, and $\delta$ is a dummy variable for whether NREGS has rolled out in the respondent's district and year. In Columns 2 and 3, the coefficients are from the OLS estimation of Equation (1) where $S$ is a dummy variable for the child's primary activity (any work or attends school), and $\delta$ is a placebo NREGS treatment, which is equal to one if the district was in waves 1 or 2 (received NREGS in 2006 or 2007) and the year is at least 2004, one if the district was in wave 3 (received NREGS in 2008) and the year is at least 2005, and zero otherwise. No data from after the actual roll-out of NREGS is included. Standard errors clustered at the district level are reported in parentheses. ***indicates significance at $1 \%$ level, ${ }^{* *}$ at $5 \%$ level, ${ }^{*}$ at $10 \%$ level. 
A Appendix Tables 
Table A1: Effect of NREGS on Test Scores and Schooling By Gender

\begin{tabular}{|c|c|c|c|c|c|}
\hline Dep. Var: & $\begin{array}{l}\text { Math } \\
\text { Score }\end{array}$ & $\begin{array}{l}\text { Total Math } \\
\text { Score }\end{array}$ & $\begin{array}{l}\text { Reading } \\
\text { Score }\end{array}$ & $\begin{array}{c}\text { Currently } \\
\text { Enrolled }\end{array}$ & $\begin{array}{c}\text { Current } \\
\text { Grade }\end{array}$ \\
\hline & \multicolumn{5}{|c|}{ Panel A: Ages 13-16 } \\
\hline NREGS & $\begin{array}{l}-.02 \\
(.02)\end{array}$ & $\begin{array}{l}-.11 \\
(.03)^{* * *}\end{array}$ & $\begin{array}{l}-.03 \\
(.02)^{*}\end{array}$ & $\begin{array}{c}.008 \\
(.005)\end{array}$ & $\begin{array}{l}-.1 \\
(.04)^{* *}\end{array}$ \\
\hline NREGS X Female & $\begin{array}{c}-.006 \\
(.01)\end{array}$ & $\begin{array}{l}-.04 \\
(.02)^{* *}\end{array}$ & $\begin{array}{c}-.007 \\
(.01)\end{array}$ & $\begin{array}{l}.0002 \\
(.004)\end{array}$ & $\begin{array}{c}-.007 \\
(.03)\end{array}$ \\
\hline Observations & 689,938 & 689,938 & 692,125 & 732,543 & 647,604 \\
\hline Mean DV (Boys) & 3.48 & 4.20 & 3.60 & 0.88 & 7.71 \\
\hline \multirow[t]{2}{*}{ Mean DV (Girls) } & 3.37 & 4.03 & 3.53 & 0.86 & 7.70 \\
\hline & \multicolumn{5}{|c|}{ Panel B: Ages 5-12 } \\
\hline NREGS & $\begin{array}{l}.01 \\
(.02)\end{array}$ & $\begin{array}{l}-.03 \\
(.03)\end{array}$ & $\begin{array}{l}.02 \\
(.02)\end{array}$ & $\begin{array}{c}.004 \\
(.002)\end{array}$ & $\begin{array}{l}-.01 \\
(.02)\end{array}$ \\
\hline NREGS X Female & $\begin{array}{l}-.005 \\
(.008)\end{array}$ & $\begin{array}{l}-.03 \\
(.01)^{* *}\end{array}$ & $\begin{array}{l}.0005 \\
(.009)\end{array}$ & $\begin{array}{r}-.001 \\
(.001)\end{array}$ & $\begin{array}{l}-.01 \\
(.01)\end{array}$ \\
\hline Observations & $1,874,538$ & $1,874,538$ & $1,886,545$ & $1,929,268$ & $1,835,677$ \\
\hline Mean DV (Boys) & 2.35 & 2.65 & 2.42 & 0.97 & 3.52 \\
\hline Mean DV (Girls) & 2.28 & 2.57 & 2.37 & 0.96 & 3.50 \\
\hline Age FEs & $\overline{\text { YES }}$ & $\overline{\text { YES }}$ & $\overline{\text { YES }}$ & 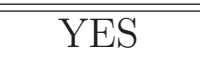 & $\overline{\text { YES }}$ \\
\hline District FEs & YES & YES & YES & YES & YES \\
\hline Year FEs & YES & YES & YES & YES & YES \\
\hline Year X Female FEs & YES & YES & YES & YES & YES \\
\hline District X Female FEs & YES & YES & YES & YES & YES \\
\hline
\end{tabular}

Source: ASER (2005-2009)

Notes: This table reports estimates of $\beta_{1}$, the effect of NREGS on math and reading test scores and schooling outcomes from the ASER data. The coefficients are estimates of $\beta_{1}$ from the OLS estimation of Equation (1) where $S$ is the listed dependent variable, and $\delta$ is a dummy variable for whether NREGS has rolled out in the respondent's district and year. Math score ranges from 0-4, total math score ranges from 0-6, and read score ranges from 0-4. All panels include year child age, and district fixed effects. Standard errors clustered at the district level are reported in parentheses. $* * *$ indicates significance at $1 \%$ level, $* *$ at $5 \%$ level, * at $10 \%$ level. 
Table A2: Robustness: Effect of NREGS on Test Scores and Schooling (with Wave-Trends)

\begin{tabular}{lccccc}
\hline Dep. Var: & $\begin{array}{c}\text { Math } \\
\text { Score }\end{array}$ & $\begin{array}{c}\text { Total Math } \\
\text { Score }\end{array}$ & $\begin{array}{c}\text { Reading } \\
\text { Score }\end{array}$ & $\begin{array}{c}\text { Currently } \\
\text { Enrolled }\end{array}$ & $\begin{array}{c}\text { Current } \\
\text { Grade }\end{array}$ \\
\hline NREGS & \multicolumn{5}{c}{ Panel A: Full Sample } \\
& -.006 & -.08 & .008 & -.003 & -.05 \\
Observations & $(.02)$ & $(.03)^{* * *}$ & $(.02)$ & $(.003)$ & $(.02)^{* *}$ \\
Mean DV & $2,564,476$ & $2,564,476$ & $2,578,670$ & $2,661,811$ & $2,483,281$ \\
\hline \hline & 2.61 & 3.02 & 2.71 & .94 & 4.60 \\
\hline \hline NREGA & -.02 & -.1 & -.02 & -.004 & -.09 \\
& $(.02)$ & $(.03)^{* * *}$ & $.02)$ & $(.005)$ & $(.05)^{*}$ \\
Observations & 689,938 & 689,938 & 692,125 & 732,543 & 647,604 \\
Mean DV & 3.43 & 4.12 & 3.57 & .87 & 7.66 \\
\hline \hline \multicolumn{5}{c}{ Panel B: Ages $13-16$} \\
\hline \hline NREGS & .003 & -.05 & .02 & -.001 & -.009 \\
Observations & $1,874,538$ & $1,874,538$ & $1,886,545$ & $1,929,268$ & $1,835,677$ \\
Mean DV & 2.32 & 2.62 & 2.40 & .96 & 3.51 \\
\hline \hline District FEs & YES & YES & YES & YES & YES \\
Age FEs & YES & YES & YES & YES & YES \\
Year FEs & YES & YES & YES & YES & YES \\
Wave*Year Trends & YES & YES & YES & YES & YES \\
\hline
\end{tabular}

Source: Source: ASER 2005-2009

Notes: This table reports estimates of $\beta_{1}$, the effect of NREGS on math and reading test scores and schooling outcomes from the ASER data. Math score ranges from 0-4, total math score ranges from 0-6, and read score ranges from 0-4. All panels include year, child age, and district fixed effects and wave* year fixed effects. Standard errors clustered at the district level are reported in parentheses. $* * *$ indicates significance at $1 \%$ level, ${ }^{*}$ at $5 \%$ level, ${ }^{*}$ at $10 \%$ level. 
Table A3: Robustness: Effect of NREGS on Test Scores and Schooling (with Rainfall Controls)

\begin{tabular}{|c|c|c|c|c|c|}
\hline Dep. Var: & $\begin{array}{l}\text { Math } \\
\text { Score }\end{array}$ & $\begin{array}{l}\text { Total Math } \\
\text { Score }\end{array}$ & $\begin{array}{l}\text { Reading } \\
\text { Score }\end{array}$ & $\begin{array}{l}\text { Currently } \\
\text { Enrolled }\end{array}$ & $\begin{array}{l}\text { Current } \\
\text { Grade }\end{array}$ \\
\hline & \multicolumn{5}{|c|}{ Panel A: Full Sample } \\
\hline NREGS & $\begin{array}{c}-.0006 \\
(.02)\end{array}$ & $\begin{array}{l}-.08 \\
(.03)^{* * *}\end{array}$ & $\begin{array}{l}.001 \\
(.02)\end{array}$ & $\begin{array}{l}. .006 \\
(.003)^{* *}\end{array}$ & $\begin{array}{l}-.05 \\
(.02)^{* *}\end{array}$ \\
\hline Observations & $2,564,476$ & $2,564,476$ & $2,578,670$ & $2,661,811$ & $2,483,281$ \\
\hline \multirow[t]{2}{*}{ Mean DV } & 2.61 & 3.02 & 2.71 & .94 & 4.60 \\
\hline & \multicolumn{5}{|c|}{ Panel B: Ages 13-16 } \\
\hline NREGS & $\begin{array}{l}-.03 \\
(.02)\end{array}$ & $\begin{array}{l}-.13 \\
(.03)^{* * *}\end{array}$ & $\begin{array}{l}-.04 \\
(.02)^{*}\end{array}$ & $\begin{array}{l}-.009 \\
(.005)^{*}\end{array}$ & $\begin{array}{l}-.11 \\
(.04)^{* *}\end{array}$ \\
\hline Observations & 689,938 & 689,938 & 692,125 & 732,543 & 647,604 \\
\hline \multirow[t]{2}{*}{ Mean DV } & 3.43 & 4.12 & 3.57 & .87 & 7.66 \\
\hline & \multicolumn{5}{|c|}{ Panel C: Ages 5-12 } \\
\hline NREGS & $\begin{array}{l}.007 \\
(.02)\end{array}$ & $\begin{array}{l}. .05 \\
(.03)\end{array}$ & $\begin{array}{l}.01 \\
(.02)\end{array}$ & $\begin{array}{l}-.004 \\
(.002)^{*}\end{array}$ & $\begin{array}{l}-.02 \\
(.02)\end{array}$ \\
\hline Observations & $1,874,538$ & $1,874,538$ & $1,886,545$ & $1,929,268$ & $1,835,677$ \\
\hline Mean DV & 2.32 & 2.61 & 2.40 & .96 & 3.51 \\
\hline District FEs & YES & YES & YES & YES & YES \\
\hline Year FEs & YES & YES & YES & YES & YES \\
\hline Age FEs & YES & YES & YES & YES & YES \\
\hline Rainfall Controls & YES & YES & YES & YES & YES \\
\hline
\end{tabular}

Source: ASER 2005-2009

Notes: This table reports estimates of $\beta_{1}$, the effect of NREGS on math and reading test scores and schooling outcomes from the ASER data. Math score ranges from 0-4, total math score ranges from 0-6, and read score ranges from 0-4. All panels include year, child age, and district fixed effects and controls for rainfall this year and rainfall last year. Standard errors clustered at the district level are reported in parentheses. $* * *$ indicates significance at $1 \%$ level, $* *$ at $5 \%$ level, $*$ at $10 \%$ level. 
Table A4: Robustness: Effect of NREGS on Test Scores and Schooling (ITT)

\begin{tabular}{|c|c|c|c|c|c|}
\hline Dep. Var: & $\begin{array}{l}\text { Math } \\
\text { Score }\end{array}$ & $\begin{array}{c}\text { Total Math } \\
\text { Score }\end{array}$ & $\begin{array}{l}\text { Reading } \\
\text { Score }\end{array}$ & $\begin{array}{l}\text { Currently } \\
\text { Enrolled }\end{array}$ & $\begin{array}{l}\text { Current } \\
\text { Grade }\end{array}$ \\
\hline \multicolumn{6}{|c|}{ Panel A: Full Sample } \\
\hline NREGS & $\begin{array}{l}-.02 \\
(.02)\end{array}$ & $\begin{array}{l}-13 \\
(.03)^{* * *}\end{array}$ & $\begin{array}{l}.01 \\
(.02)\end{array}$ & $\begin{array}{l}-.006 \\
(.003)^{*}\end{array}$ & $\begin{array}{l}-.05 \\
(.02)^{* *}\end{array}$ \\
\hline Observations & $2,055,034$ & $2,055,034$ & $2,065,228$ & $2,126,570$ & $1,994,536$ \\
\hline Mean DV & 2.58 & 2.97 & 2.68 & 0.93 & 4.58 \\
\hline \multicolumn{6}{|c|}{ Panel B: Ages 13-16 } \\
\hline NREGS & $\begin{array}{l}-.03 \\
(.02)\end{array}$ & $\begin{array}{l}-.15 \\
(.04)^{* * *}\end{array}$ & $\begin{array}{l}.04 \\
(.02)^{*}\end{array}$ & $\begin{array}{l}-.008 \\
(.005)\end{array}$ & $\begin{array}{l}-.09 \\
(.05)^{*}\end{array}$ \\
\hline Observations & 545,055 & 545,055 & 546,495 & 576,250 & 509,354 \\
\hline Mean DV & 3.40 & 4.08 & 3.55 & 0.86 & 7.66 \\
\hline \multicolumn{6}{|c|}{ Panel C: Ages 5-12 } \\
\hline NREGS & $\begin{array}{l}-.02 \\
(.02)\end{array}$ & $\begin{array}{l}-.11 \\
(.03)^{* * *}\end{array}$ & $\begin{array}{c}-.008 \\
(.02)\end{array}$ & $\begin{array}{l}-.005 \\
(.003)^{*}\end{array}$ & $\begin{array}{l}-.03 \\
(.02)^{*}\end{array}$ \\
\hline Observations & $1,509,979$ & $1,509,979$ & $1,518,733$ & $1,550,320$ & $1,485,182$ \\
\hline Mean DV & 2.28 & 2.57 & 2.37 & 0.96 & 3.52 \\
\hline District FEs & YES & YES & YES & YES & YES \\
\hline Age FEs & YES & YES & YES & YES & YES \\
\hline Year FEs & YES & YES & YES & YES & YES \\
\hline
\end{tabular}

Source: ASER 2005-2009

Notes: This table reports estimates of $\beta_{1}$, the effect of NREGS on math and reading test scores and schooling outcomes from the ASER data. The The coefficients are from the OLS estimation of Equation (1) where $S$ is a dummy variable which is equal to one if the district would have gotten the NREGS program had their state allotted slots in the program solely based on backwardness rank, and $\delta$ is a dummy variable for whether NREGS has rolled out in the respondent's district and year. Math score ranges from 0-4, total math score ranges from 0-6, and read score ranges from 0-4. All panels include year, child age, and district fixed effects. Standard errors clustered at the district level are reported in parentheses. $* * *$ indicates significance at $1 \%$ level, ${ }^{* *}$ at $5 \%$ level, ${ }^{*}$ at $10 \%$ level. 
Table A5: Children's Primary Activity (Ages 5-12)

\begin{tabular}{lcccc}
\hline Dep. Var: & $\begin{array}{c}\text { Works at } \\
\text { Home }\end{array}$ & $\begin{array}{c}\text { Works outside } \\
\text { Home }\end{array}$ & $\begin{array}{c}\text { Domestic } \\
\text { Work }\end{array}$ & $\begin{array}{c}\text { Attends } \\
\text { School }\end{array}$ \\
\hline NREGS & -.001 & .0009 & .003 & .002 \\
& $(.002)$ & $(.0008)$ & $(.002)$ & $(.007)$ \\
Observations & 254,982 & 254,982 & 254,982 & 254,982 \\
Mean of DV & .007 & .004 & .016 & .85 \\
\hline \hline District FEs & YES & YES & YES & YES \\
Age FEs & YES & YES & YES & YES \\
Year FEs & YES & YES & YES & YES \\
\hline
\end{tabular}

Source: NSS 2003-2009 (rounds 60, 61, 62, 64, 66)

Notes: This table reports estimates of $\beta_{1}$, the effect of NREGS on primary activities of children ages 5-12 using the NSS. The coefficients are from the OLS estimation of Equation (1) where $S$ is a dummy for each specified primary activity (market work at home, market work outside the home, domestic work, or school attendance), and $\delta$ is a dummy variable for whether NREGS has rolled out in the respondent's district and year. Standard errors clustered at the district level are reported in parentheses. $* * *$ indicates significance at $1 \%$ level, ${ }^{* *}$ at $5 \%$ level, $*$ at $10 \%$ level. 